\title{
Investigation of Air and Air-Steam Gasification of High Carbon Wood Ash in a Fluidized Bed Reactor
}

\author{
Adrian K. James $^{1}$, Steve S. Helle ${ }^{2}$, Ronald W. Thring ${ }^{2}$, P. Michael Rutherford ${ }^{2} \&$ Mohammad S. Masnadi $^{3}$ \\ ${ }^{1}$ Natural Resource and Environmental Science, University of Northern British Columbia, Prince George, BC, \\ Canada \\ ${ }^{2}$ Environmental Science \& Engineering, University of Northern British Columbia, Prince George, BC, Canada \\ ${ }^{3}$ Chemical and Biological Engineering, University of British Columbia, Vancouver, BC, Canada \\ Correspondence: Ronald W. Thring, Environmental Science \& Engineering, University of Northern British \\ Columbia, Prince George, BC, Canada. Tel: 1-250-301-8141. E-mail: thring@unbc.ca
}

Received: October 25, 2013 Accepted: November 11, 2013 Online Published: January 6, 2014

doi:10.5539/eer.v4n1p15 URL: http://dx.doi.org/10.5539/eer.v4n1p15

\begin{abstract}
The pulp and paper industry in an effort to offset fossil fuel demand uses woody biomass combustion as a renewable energy source to meet their ever-growing energy demands. Boiler combustion systems are often used to provide this energy. However, large amounts of high carbon ash are produced from some boilers resulting in technological, economic and environmental challenge. This high carbon ash is considered to be of very little economic and environmental value and is typically sent to landfills. Reuse of this ash in some boilers requires upgrading and is not economically feasible. Therefore, this study investigates the feasibility of gasifying high carbon wood ash of particle sizes smaller than $3 \mathrm{~mm}$, while comparing its behaviour to that of unburned wood. Gasification was conducted in a stainless steel bubbling fluidized bed reactor 3-inch diameter and height of approximately $800 \mathrm{~mm}$ using air and air-steam as gasifying agents. Parameters of interest included equivalence ratio (ER), gas calorific value, carbon conversion efficiency and produced gas yield. High carbon ash was successfully gasified at low temperatures and atmospheric pressure and showed similar trends as woody biomass. The higher heating value (HHV) and carbon conversion efficiency increased with increasing temperature. The $\mathrm{H}_{2} / \mathrm{CO}$ molar ratio was higher for the air-steam process. Future areas of research could include investigating the viability of producing a gas of even higher heating value.
\end{abstract}

Keywords: gasification, fluidized bed reactor, high carbon wood ash, air/air-steam gasification, higher heating value, carbon conversion

\section{Introduction}

The pulp and paper industry produces large volumes of high carbon ash from boilers. While the carbon content is relatively high in this residue, the energy content of all of the ash produced is approximately $1 \%$ of the energy content of the wood. Combustion of the high carbon ash presents a number of operational problems such as corrosion and scouring. Due to the design of some boilers the ash may be carried by the flue gas through the boiler tubes creating problems. The variation in particle sizes also causes inherent problems in a fixed bed system. Fixed bed systems usually require a uniform feedstock to avoid channelling (Warnecke, 2000; Ryu et al., 2006). Exorbitant costs are also associated with design and system alterations.

High carbon ash is considered to have very little potential economic and environmental benefit at this stage and is typically sent to landfills. The application of bottom ash as a soil additive is restricted in British Columbia, Canada. Other options for utilizing high carbon ash must be explored, including use as a low cost feedstock for already existing gasifiers in order to recover as much energy as possible, while reducing ash volume.

Biomass gasification is a thermo-chemical process of gaseous fuel production by partial oxidation of a solid fuel to produce heat, electricity and synthesis gas (Rade \& Karamarkovic, 2010). Gasification results in producer gas containing $\mathrm{CO}, \mathrm{H}_{2}, \mathrm{CnHx}$ and other gases (Turare, 1997). The main objective is to generate a combustible gas rich in $\mathrm{CO}, \mathrm{H}_{2}$ and $\mathrm{CH}_{4}$ with a medium to high lower heating value (LHV) (Alauddin, Lahijani, Mohammadi, \& Mohamed, 2010; Skoulou, Koufodimos, Samaras, \& Zabanioutou, 2008). Operating conditions such as temperature, equivalence ratio (ER) and steam/biomass (S/B) ratio play important roles in biomass gasification. 
Bed temperature is one of the most important operating parameters in gasification, affecting both the heating value and the producer gas composition (Alauddin et al., 2010). The heat needed for air gasification is provided by partial combustion of the biomass. High temperatures increase $\mathrm{CO}_{2}$ production, lowering the heating value of the produced gas. A high bed temperature improves carbon conversion and steam cracking and reforming of tars, resulting in less char, reduced tar formation and higher gas yields (Alauddin et al., 2010; Pinto et al., 2003; Chairprast \& Vitidsant, 2009).

The equivalence ration (ER) also strongly influences the gasification product composition. More combustion occurs at high ER, increasing $\mathrm{CO}_{2}$ production (Alauddin et al., 2010; Mandl, Obernberger, \& Biedermann, 2010) A higher air flow rate results in higher gas velocities, improving the combustion of solid char due to improved oxygen mass transfer (Mandl et al., 2010; Natarajan, Nordin, \& Rao, 1998). An equivalence ratio of $0.2-0.3$ is most favourable for producing CO-rich gas ( $\mathrm{Li}$ et al., 2004). When steam is the gasifying agent, $\mathrm{H}_{2}$ and $\mathrm{CO}_{2}$ increase, while CO decreases due to the water gas shift reaction (Devi, Ptasinski, \& Janssen, 2003).

Fluidized bed reactors have been widely applied for gasification, pyrolysis and combustion of a wide range of particulate materials including biomass (Cui \& Grace, 2007). Advantages include high heat transfer, uniform and controllable temperatures, favourable gas-solid contact and the ability to handle a wide range of particulate properties such as particle diameter. Fluidized bed reactors also accommodate wide variations in fuel quality.

Air-blown biomass gasification produces low calorific value gases, with higher heating values (HHV) of 4-7 $\mathrm{MJ} / \mathrm{Nm}^{3}$, whereas oxygen and steam-blown processes result in a HHV of $10-18 \mathrm{MJ} / \mathrm{Nm}^{3}$ ( $\mathrm{Li}$ et al., 2004). Circulating fluidized bed (CFB) tests using various feedstocks such as, spruce-pine-fir sawdust mixture, 1:1 ratio of pine bark and spruce whitewood mix, cypress, hemlock and cedar-hemlock mixtures have produced gases with HHV from 2.43-6.13 MJ/kg, with either air or air-steam as the gasifying agent. For example, in a fluidized bed experiment at atmospheric temperature, the gasification of pine sawdust produced a LHV of 6.74-9.14 $\mathrm{MJ} / \mathrm{Nm}^{3}$ in an air-steam medium at $\mathrm{ER}=0.22$ (Lv et al., 2004).

The research carried out in this study was intended to determine the feasibility of gasifying high carbon wood ash particles smaller than $3 \mathrm{~mm}$ to identify whether they behave similarly to unburned wood when gasified. Test were carried out to,

(1) Determine the range of equivalence ratios for stable operation.

(2) Determine the calorific value of the producer gas with air and air-steam agents to ascertain the potential of producing a low to medium calorific value syngas.

(3) Measure the carbon conversion efficiency.

(4) Calculate the product gas yield.

\section{Experimental}

\subsection{Feed Materials}

Wood ash particles from from an industrial scale fixed-bed boiler (Canfor Pulp Mill, Prince George, BC) constituted the feedstock in study. Hog fuel is used in this boiler, comprised predominantly of softwood sawmill waste derived from pine wood. Silica sand was the inert bed material. The proximate and ultimate analyses of the ash are provided in Table 1.

Table 1. Proximate and ultimate analyses of hog fuel

\begin{tabular}{ll}
\hline Higher heating value $(\mathrm{MJ} / \mathrm{kg})$ & 11.60 \\
Proximate analysis (wt.\% dry basis) & \\
Volatile Matter & 21.5 \\
Fixed Carbon & 28.8 \\
Ash & 49.7 \\
& \\
Ultimate analysis (wt. \% dry basis) & \\
$\mathrm{C}$ & 48.5 \\
$\mathrm{H}$ & 0.9 \\
\hline
\end{tabular}




\begin{tabular}{lc}
\hline $\mathrm{O}$ & 33.4 \\
$\mathrm{~N}$ & 0.2 \\
$\mathrm{~S}$ & 0 \\
Other ash forming elements & 17.0 \\
\hline
\end{tabular}

$\mathrm{O}$ - Calculated by difference.

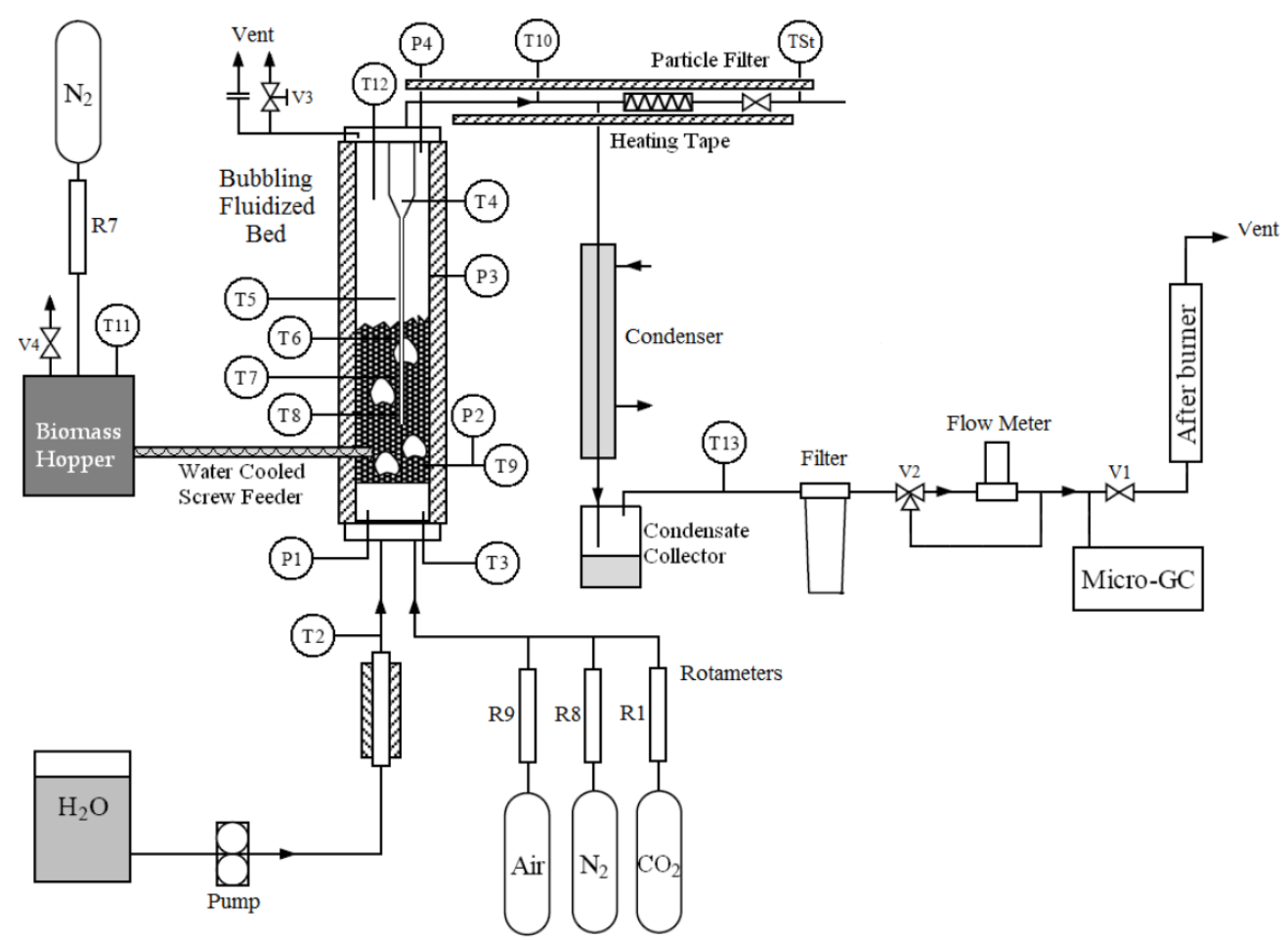

Figure 1. Schematic diagram of experimental unit for biomass air and air-steam gasification in a bubbling fluidized bed. T - Thermocouple P- Pressure sensor R - Rotameter

\subsection{Gasificaion Setup}

Air gasification and air-steam gasification were carried out in the lab-scale bubbling fluidized bed reactor shown schematically in Figure 1. Constructed from 310 stainless steel 3-inch diameter (nominal) pipes (I.D. $=77.9 \mathrm{~mm}$ ) of height of approximately $800 \mathrm{~mm}$. Two electrical heaters supplied heat to the reactor. The reactor was charged with $1.4 \mathrm{~kg}$ of sand as bed material. A pressure tap located in the biomass feeder was used to control and facilitate the discharge of feedstock. The bed was fluidized by air and nitrogen introduced below the distributor. Water was pumped to the reactor, then vapourized, with its flow rate measured by a steam flow meter. The biomass feedstock was fed from the side of the reactor through an atomizer nozzle, covered by a cooling jacket to keep the feedstock temperature below $80^{\circ} \mathrm{C}$, to avoid plugging by thermal decomposition. The product gas left the reactor at the top and passed through a cyclone to return solid to the gasification bed. Excess steam in the product gas was separated by a condenser, while fine ash and char particles were captured by an internal cyclone, supplemented by a filter after the condenser and a waste bin. The product gas flow rate was measured by a rotameter combined with a thermocouple and a pressure transducer.

\subsection{Experimental Procedure}

The feedstock was added to the hopper prior to each experimental run. The gasifier and furnace heaters for air preheating were turned on, and controllers were set at the selected operating temperatures. With sand as the bed material, the reactor was charged with $\sim 7 \mathrm{~L} / \mathrm{min}$ of nitrogen to assist with fluidization and aid heat transfer. The feedstock was then fed at $176 \mathrm{~g} / \mathrm{h}$, with an air supply of $0.282 \mathrm{Nm}^{3} / \mathrm{h}$ from the bottom of the reactor to provide an ER of 0.12. When the system reached steady state, gas samples were taken at 4 min intervals. Experiments were conducted at various bed temperatures within the range of $650-770{ }^{\circ} \mathrm{C}$. The reactor was then operated at a fixed temperature of $775^{\circ} \mathrm{C}$ while varying the ER. 
For air-steam gasification, water was introduced to the reactor to provide different steam/biomass (S/B) ratios at a fixed temperature of $715^{\circ} \mathrm{C}$ and a fixed ER of 0.12 , with gas sampling as for air alone.

\subsection{Gas Analysis}

The concentrations of $\mathrm{H}_{2}, \mathrm{~N}_{2}, \mathrm{CO}, \mathrm{CO}_{2}$ and $\mathrm{C}_{n} \mathrm{H}_{\mathrm{x}}$ were measured by a micro-gas chromatograph $\mathrm{CP}-4900$ (Varian Inc.) equipped with a $\mathrm{CO}_{\mathrm{x}}$ column and a thermal conductivity detector.

\subsection{Analyses of Experimental Results}

To assess the gasification process, variables such as Equivalence Ratio (ER), carbon conversion efficiency and higher heating values (HHV) were determined as follows.

$$
\begin{gathered}
E R=\frac{\text { mas flow of air } / \text { mass flow dry biomass }}{\text { stoichiometric air } / \text { biomass ratio }} \\
S / B=\frac{\text { steam feed rate }+ \text { moisture introduced } \text { with } \text { fuel }(\mathrm{g} / \mathrm{h})}{\text { Total fuel feed rate }(\mathrm{g} / \mathrm{h})} \\
\text { Carbon conversion efficiency }=\frac{\text { gas velocity } x 1000[\mathrm{CO} \%+\mathrm{CO} \%+3(\mathrm{C} 3 \mathrm{H} 8 \%)] \frac{12}{24.79}}{\text { biomass } \text { feed flow rate } \times \mathrm{C} \%}
\end{gathered}
$$

where produced gases are in volume $\%$, gas flow rate is $\left(\mathrm{Nm}^{3} / \mathrm{h}\right)$, feed flow rate $(\mathrm{g} / \mathrm{h})$ and $\mathrm{C} \%$, is the biomass percent carbon based on the ultimate analysis. The higher heating value is estimated from

$$
\mathrm{HHV}=\left(12.75 \mathrm{H}_{2}+12.63 \mathrm{CO}+39.82 \mathrm{CH}_{4}+63.43 \mathrm{C}_{2} \mathrm{H}_{4}+99 \mathrm{C}_{3} \mathrm{H}_{8} \ldots\right) / 100
$$

where the species contents are in mol\% and their heats of combustion are in MJ/Nm3 (Li et al., 2004; Zhang, 2011).

\section{Results}

\subsection{Air Gasification}

\subsubsection{Effect of Reactor Temperature}

Analysis of the gas produced was carried out for reactor temperatures ranging from $\sim 650$ to $\sim 770{ }^{\circ} \mathrm{C}$ in increments of approximately $30{ }^{\circ} \mathrm{C}$. From Figure 2, it can be seen that the $\mathrm{CO}$ concentration increased with temperature. All other gas concentrations remained nearly constant, except for $\mathrm{CO}_{2}$ whose concentration decreased with increasing temperature. The gases produced were predominantly influenced by the reactions:

$$
\begin{array}{cr}
\mathrm{C}+\frac{1}{2} \mathrm{O}_{2} \rightarrow \mathrm{CO} & \text { partial oxidation (5) } \\
\mathrm{C}+\mathrm{O}_{2} \rightarrow \mathrm{CO}_{2} & \\
\mathrm{CO}+\mathrm{H}_{2} \mathrm{O} \leftrightarrow \mathrm{CO}_{2}+\mathrm{H}_{2} & \text { complete combustion (6) }
\end{array}
$$

Hence the $\mathrm{C}$ present in the fuel as char reacted directly with the $\mathrm{O}$ supplied by the air to produce $\mathrm{CO}$, an exothermic reaction. $\mathrm{CO}$ production favoured higher temperatures, resulting in less $\mathrm{CO}_{2}$ generation with increasing temperature. The reactions were being carried out at ER $=0.12$, below the ideal ER range of $0.2-0.3$ (Li et al., 2004). The limited $\mathrm{O}_{2}$ fed resulted in a high $\mathrm{CO}: \mathrm{CO}_{2}$ ratio. This would result in greater concentrations of $\mathrm{CO}$ instead of $\mathrm{CO}_{2}$. The $\mathrm{H}_{2}$ concentration remained low and relatively constant, in part because there was very little $\mathrm{H}$ in the fuel. $\mathrm{CH}_{4}$ could not be detected but propane was found at very low concentrations. Table 2 summarizes the results when temperature was varied during air gasification. The carbon conversion efficiency increased from 31.2 to $52.9 \%$, with increasing temperature, limited by the low $\mathrm{H}$ content and the lack of $\mathrm{O}$ to the reactor. The higher heating values increased with increasing temperature from 0.77 to $1.64 \mathrm{MJ} / \mathrm{Nm}^{3}$. $\mathrm{HHV}$, increased by $\sim 40 \%$ between 657 and $675{ }^{\circ} \mathrm{C}$ and between 675 and $698{ }^{\circ} \mathrm{C}$, thereafter approximately $10 \%$ for each temperature rise studied. The monotonic increase resulted from improved carbon conversion at higher temperatures. The gas yield ranged from 2.26 to $2.53 \mathrm{Nm}^{3} / \mathrm{kg}$ and increased for the first two temperature rises then slightly decreased at $771^{\circ} \mathrm{C}$. 


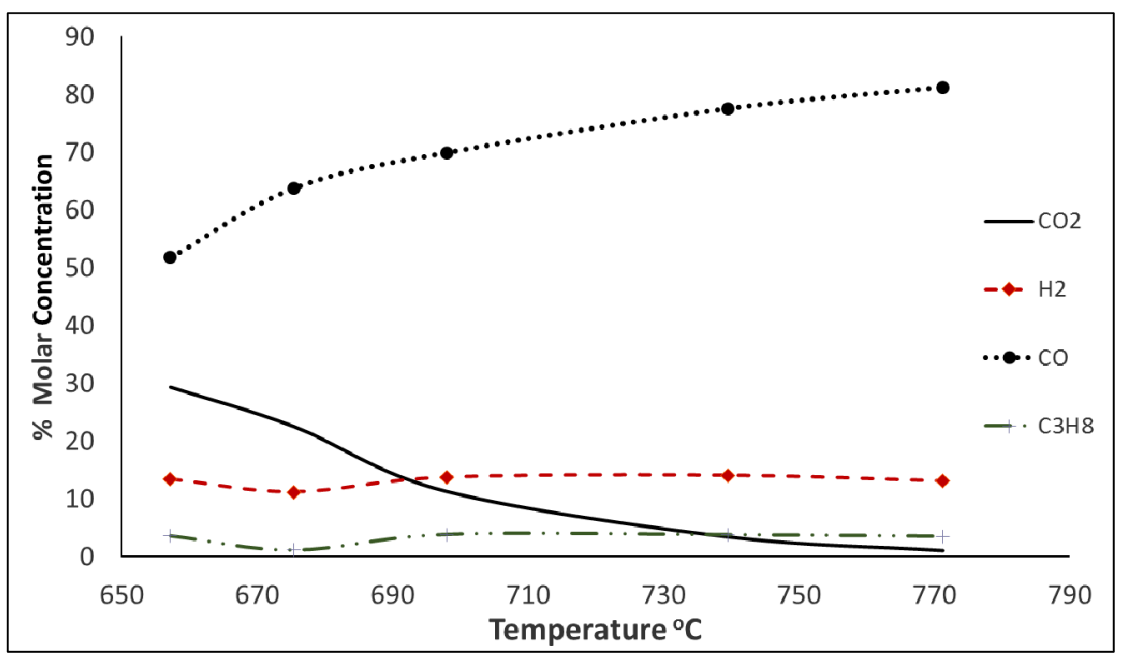

Figure 2. Effect of temperature on gas composition. Biomass feed rate: $176 \mathrm{~g} / \mathrm{h}$; ER: 0.12

Table 2. Effect of temperature on various parameters during air gasification. Biomass feed rate: $176 \mathrm{~g} / \mathrm{h}$; ER: 0.13

\begin{tabular}{lrrrrr}
\hline Lower bed temperature $\left({ }^{\circ} \mathrm{C}\right)$ & 657 & 675 & 698 & 740 & 771 \\
\hline HHV $\left(\mathrm{MJ} / \mathrm{Nm}^{3}\right)$ & 0.77 & 1.01 & 1.39 & 1.54 & 1.64 \\
Carbon conversion efficiency $(\%)$ & 31.2 & 45.6 & 48.3 & 49.9 & 52.9 \\
Gas yield $\left(\mathrm{Nm}^{3} / \mathrm{kg}\right)$ & 2.26 & 2.49 & 2.53 & 2.53 & 2.48 \\
\hline
\end{tabular}

\subsubsection{Effect of ER}

The effects of ER on a number of factors were studied, with ER ranging from 0.12 to 0.25 and the reactor temperature $775{ }^{\circ} \mathrm{C}$. While $\mathrm{CO}$ concentrations remained relatively constant, the concentration of $\mathrm{H}$ decreased, while that of $\mathrm{CO}_{2}$ increased, with ER increasing from 0.12 to 0.25 . The $\mathrm{CO}$ concentration was higher than that of the other gases for all ER studied. The most significant variation in the gases under study was in $\mathrm{CO}_{2}$, with the other gases showed very little change in concentration. The carbon conversion efficiency increased from 52.9 to $89.9 \%$ as ER increased from 0.12 to 0.25 , resulting from increased $\mathrm{CO}_{2}$ ( $\mathrm{Lv}$ et al., 2004). The calculated HHV, including $\mathrm{N}$, ranged from 1.64 to $2.38 \mathrm{MJ} / \mathrm{Nm}^{3}$ as shown in Table 3. The HHVs recorded when ER was varied were higher than when the effect of temperature was investigated. The gas production ranged from 2.48 to 2.73 $\mathrm{m}^{3} / \mathrm{kg}$. As expected, the gas production was highest for $\mathrm{ER}=0.25$.

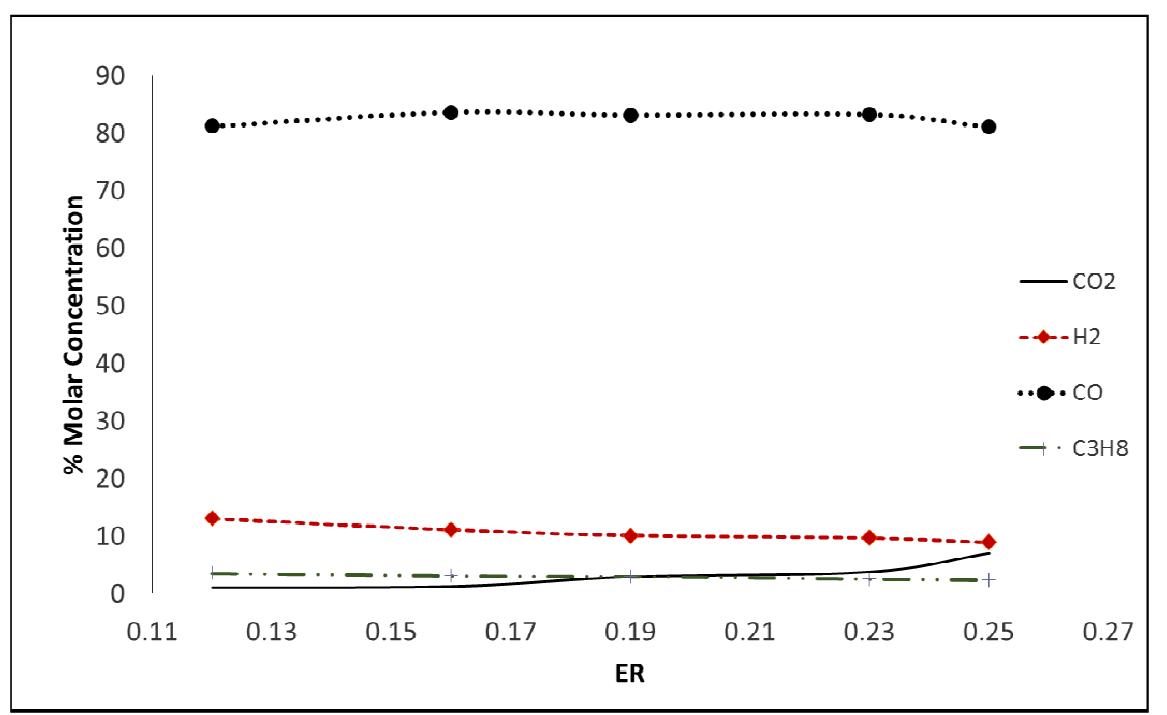


Figure 3. Effect of ER on gas composition. Biomass feed rate: $176 \mathrm{~g} / \mathrm{h}$; Temperature: $775^{\circ} \mathrm{C}$

Table 3. Effect of ER on higher heating value, carbon conversion efficiency and gas yield during air gasification Biomass feed rate: $176 \mathrm{~g} / \mathrm{h}$; Temperature: $775^{\circ} \mathrm{C}$

\begin{tabular}{llllll}
\hline ER & 0.12 & 0.16 & 0.19 & 0.23 & 0.25 \\
\hline HHV $\left(\mathrm{MJ} / \mathrm{Nm}^{3}\right)$ & 1.64 & 1.90 & 1.96 & 2.22 & 2.38 \\
Carbon conversion efficiency (\%) & 52.9 & 63.8 & 68.2 & 79.7 & 89.9 \\
Gas Yield $\left(\mathrm{Nm}^{3} / \mathrm{kg}\right)$ & 2.48 & 2.51 & 2.44 & 2.64 & 2.73 \\
\hline
\end{tabular}

\subsection{Air-Steam Gasification}

\subsubsection{Effect of Steam-Biomass Ratio}

Analysis of the gas product was carried out at $\mathrm{S} / \mathrm{B}$ ratios from 0.4 to 2.2 and a temperature of $715 \pm 5{ }^{\circ} \mathrm{C}$ with ER $\sim 0.12$. It was difficult to maintain a fixed reactor temperature since steam gasification is endothermic process. Due to the water gas shift reaction, the concentrations of $\mathrm{CO}_{2}$ and $\mathrm{H}_{2}$ increased with increasing S/B ratio, while the $\mathrm{CO}$ concentrations decreased, as seen in Figure 4.

The carbon conversion efficiency increased when the S/B ratio increased from 0.4 to 1.3 and decreased thereafter as summarized in Table 4 summarizes the results. The highest carbon conversion efficiency of $69.7 \%$ was at S/B ratio of 1.3 with a steam flow rate of $0.216 \mathrm{~kg} / \mathrm{h}$, while the lowest value, $51.3 \%$ was at $\mathrm{S} / \mathrm{B}=0.4$. HHV ranged from 1.95 to $2.50 \mathrm{MJ} / \mathrm{Nm}^{3}$. The heating value (including $\mathrm{N}_{2}$ ) reached a maximum at $\mathrm{S} / \mathrm{B}=1.7$ due to increasing production of $\mathrm{H}_{2}$, however the increasing $\mathrm{CO}_{2}$ content reduces the calorific value of the product gas (Gabra, Pettersson, Backman, \& Kjellstrom, 2001). The volume of gas produced ranged from 2.45 to $3.19 \mathrm{~m}^{3} / \mathrm{kg}$.

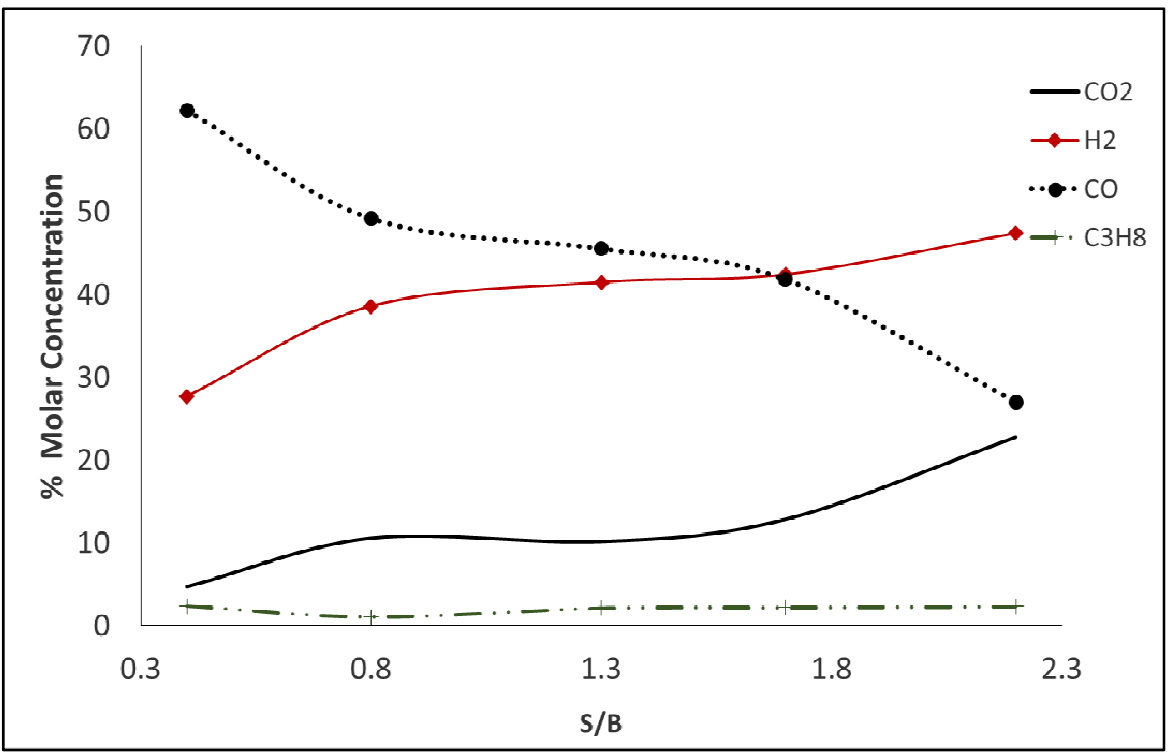

Figure 4. Effect of S/B ratio on product gas composition. Biomass feed rate: $176 \mathrm{~g} / \mathrm{h}$; Temperature: $715^{\circ} \mathrm{C}, \mathrm{ER}$ : 0.12

Table 4. Effect of S/B ratio on higher heating value, carbon conversion efficiency and gas yield during air-steam gasification for biomass feed rate: $176 \mathrm{~g} / \mathrm{h}$; ER: 0.13 ; Temperature: $715^{\circ} \mathrm{C}$

\begin{tabular}{lccccc}
\hline SB & 0.4 & 0.8 & 1.3 & 1.7 & 2.2 \\
\hline HHV $\left(\mathrm{MJ} / \mathrm{Nm}^{3}\right)$ & 1.95 & 2.29 & 2.26 & 2.50 & 2.11 \\
Carbon conversion efficiency (\%) & 51.3 & 63.2 & 69.7 & 66.7 & 54.2 \\
Gas Yield $\left(\mathrm{Nm}^{3} / \mathrm{kg}\right)$ & 2.45 & 2.93 & 3.06 & 3.19 & 2.90 \\
\hline
\end{tabular}




\subsubsection{Effect of Temperature, ER and Steam-Biomass Ratio on $\mathrm{H}_{2} / \mathrm{CO}$}

As shown in Figure 5, the molar $\mathrm{H}_{2} / \mathrm{CO}$ ratio was less than 0.3 for the temperature range investigated and decreased with increasing temperature during air blown gasification. At $775{ }^{\circ} \mathrm{C}$, all $\mathrm{H}_{2} / \mathrm{CO}$ molar ratios were below 0.17 and decreased with increasing ER. For the air-steam blown process, as the S/B ratio increased, the $\mathrm{H}_{2} / \mathrm{CO}$ molar ratio also increased. The $\mathrm{H}_{2} / \mathrm{CO}$ ratios were higher than for the air-blown processes and ranged from 0.4 to 1.75 . The injection of steam as gasifying agent increased the $\mathrm{H}_{2} / \mathrm{CO}$ molar ratio because moisture promotes both steam gasification and the water gas shift reaction (Li et al., 2004; Gabra et al., 2001).

While all three runs were at different operating conditions, the HHV can be compared at similar conditions. At $\mathrm{ER}=0.12$ and $698^{\circ} \mathrm{C}$ for the air blown process and at $715^{\circ} \mathrm{C}$ for the steam-air gasification (S/B ratio of 0.4), the HHVs (including $\mathrm{N}_{2}$ ) were $1.39 \mathrm{MJ} / \mathrm{m}^{3}$ and $1.95 \mathrm{MJ} / \mathrm{m}^{3}$ respectively. At this low $\mathrm{S} / \mathrm{B}$ ratio, the heating value for the steam fed process was approximately $29 \%$ higher than without steam.

As discussed above, the HHV increased with increasing ER and the optimum carbon conversion efficiency was found at $\mathrm{ER}=0.25$. The increase in HHV from ER of 0.12 to 0.25 was approximately $31 \%$ for the air blown process. Since the air-steam gasification was carried out at $\mathrm{ER}=0.12$, it is likely that the HHV would increase if the ER were to be increased to 0.25 , producing gas with a higher calorific value. Research on sugar cane residue (bagasse) showed that a gas generated at 3.5-4.5 MJ/ $\mathrm{Nm}^{3}$ did not present any problems when burned (Gabra et al., 2001). However, in order to obtain good burning of the gas in a turbine, combustion should be close to stoichiometric conditions. The potential of a higher heating value suggests that the product gas could be useful.

A high superficial gas velocity may cause entrainment of fine ash and carbon particles, while too low a value may result in defluidization in the reactor. While oversized particle sizes may not be fluidized and cause agglomeration (Suarez \& Beaton, 2003), the feedstock under study had a low density relative to sand. No fusing of ash or ash-sand particles was observed on visually inspecting the particles after opening the reactor after each run. Hence, the possibility of reducing the fluidizing gas velocity could be considered. Gasification with $\mathrm{N}_{2}$ as a fluidizing gas dilutes the product gas (Gil, Corella, Aznar, \& Caballero, 1999). Therefore, the calorific values (not shown here) were calculated on a $\mathrm{N}$-free basis to give an idea of the heating values likely to be achieved. The minimum fluidizing flow used for the experiments was approximately $15.0 \mathrm{~L} / \mathrm{min}$, achieved by adding $\mathrm{N}_{2}$ to give the desired operating fluidization conditions. Further investigation should be carried to reduce the fluidizing flow in an effort to produce a higher calorific value producer gas.

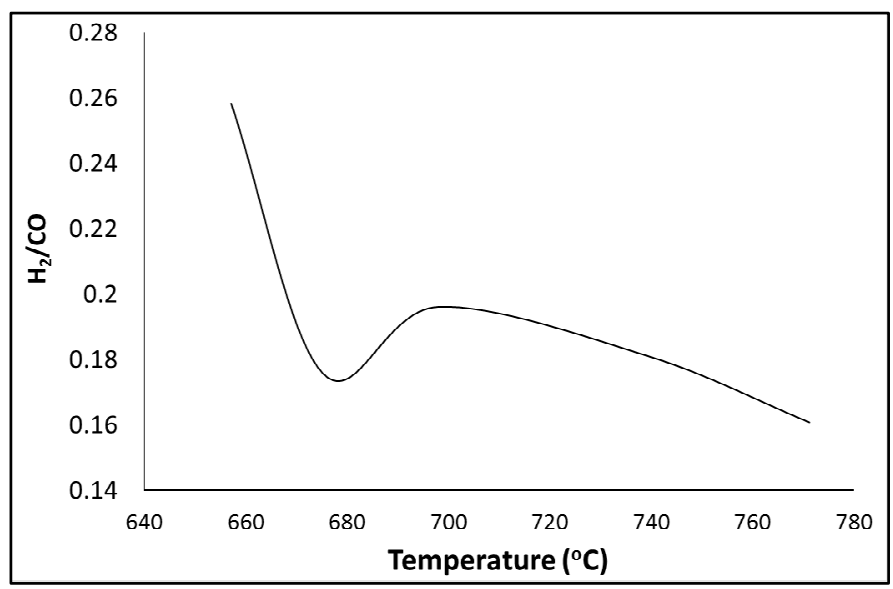

Figure $5 . \mathrm{H}_{2} / \mathrm{CO}$ molar ratio as a function of temperature for air gasification. Biomass feed rate: $176 \mathrm{~g} / \mathrm{h}$; ER: 0.12 


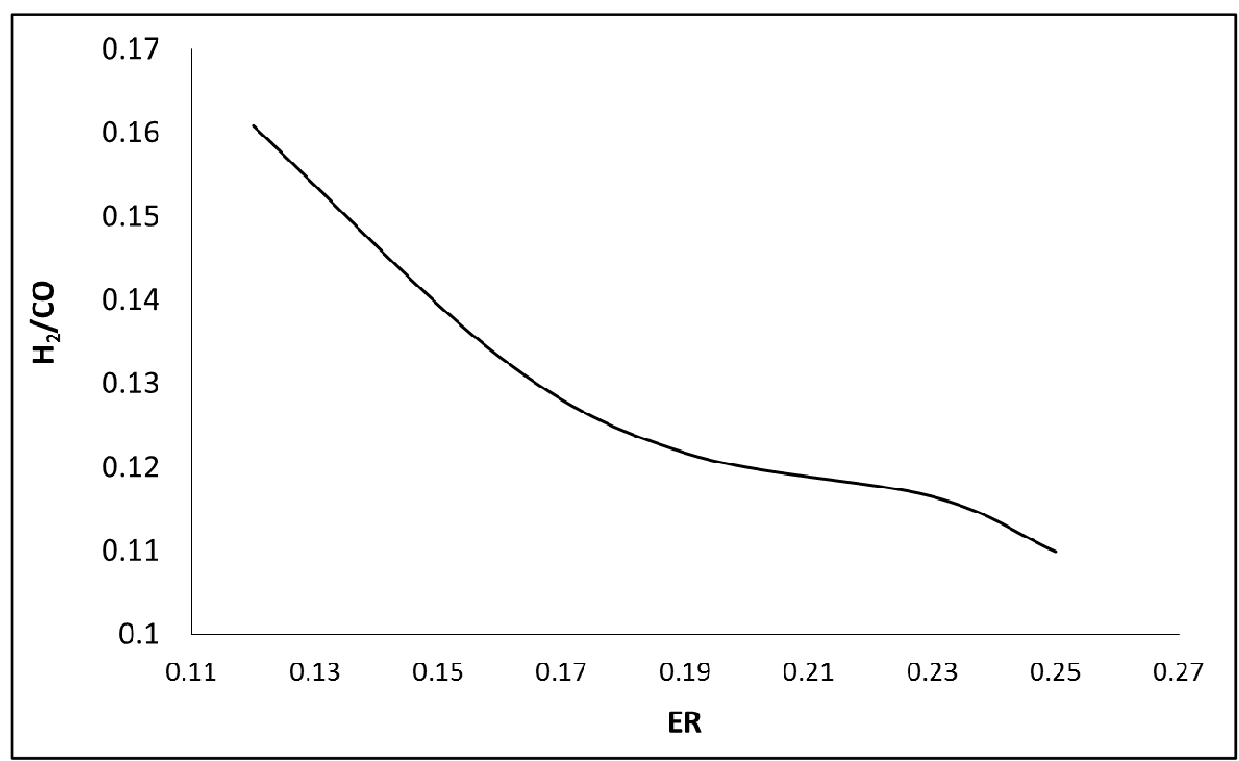

Figure $6 . \mathrm{H}_{2} / \mathrm{CO}$ molar ratio as a function of ER for air gasification. Biomass feed rate: $176 \mathrm{~g} / \mathrm{h}$; Temperature: $775^{\circ} \mathrm{C}$

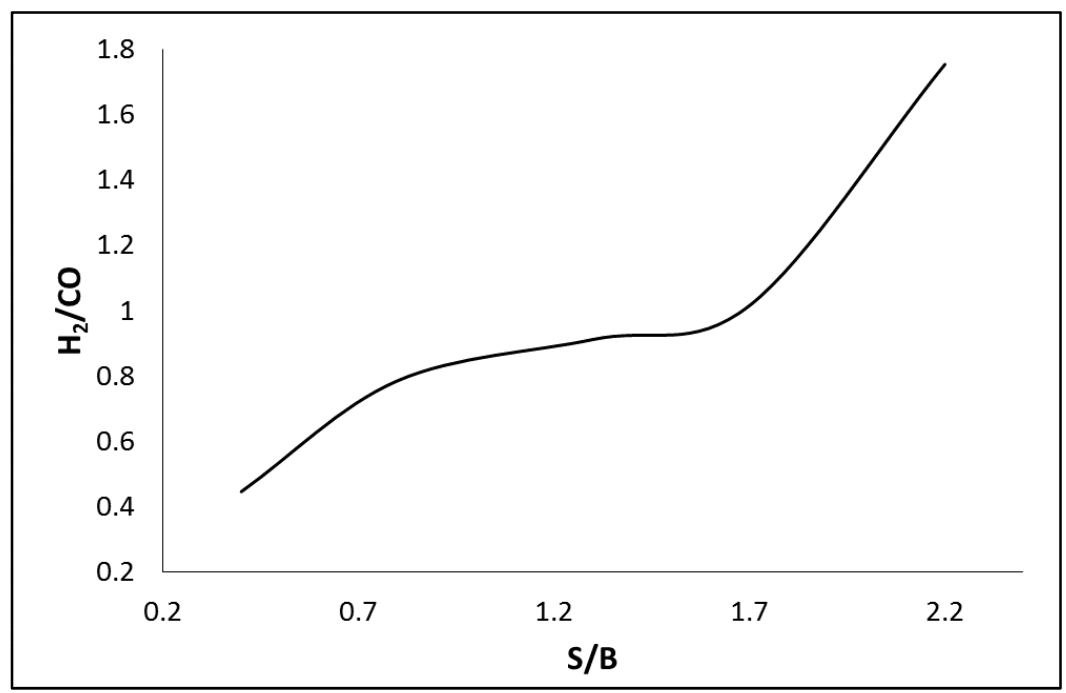

Figure 7. $\mathrm{H}_{2} / \mathrm{CO}$ molar ratio as a function of $\mathrm{S} / \mathrm{B}$ for air-steam gasification. Biomass feed rate: $176 \mathrm{~g} / \mathrm{h}$; Temperature: $715^{\circ} \mathrm{C}$; ER:0.12

\section{Conclusion}

1) High carbon ash was successfully gasified in a bubbling fluidized bed reactor at low temperatures and atmospheric pressure. Ash and woody biomass showed similar trends for gasification and product gas formation.

2) The higher heating value of the producer gas at equivalence ratios from 0.12 to 0.25 were in the range of $0.77-2.50 \mathrm{MJ} / \mathrm{Nm}^{3}$ with gas yields from $2.26-3.27 \mathrm{Nm}^{3} / \mathrm{kg}$.

3) The carbon conversion efficiency increased with increasing temperature, reaching a maximum at an ER of 0.25 .

4) $\mathrm{HHV}$ increased with increasing temperature in the range $650-770{ }^{\circ} \mathrm{C}$.

5) The heating value for the steam fed process was approximately $30 \%$ higher than without steam at otherwise similar operating conditions. 
6) The $\mathrm{H}_{2} / \mathrm{CO}$ molar ratio increased with the addition of air-steam over the range of $\mathrm{S} / \mathrm{B}$ ratio studied $(0.4$ to 2.2). For the air blown process the $\mathrm{H}_{2} / \mathrm{CO}$ ratio decreased with increasing $\mathrm{ER}$ and with increasing temperature.

7) No noticeable fusing of ash or ash-sand particles was observed on visual inspection after run completion.

\section{References}

Alauddin, Z. A. B. Z., Lahijani, P., Mohammadi, M., \& Mohamed, A. R. (2010). Gasification of lignocellulosic biomass in fluidized beds for renewable energy development: A review. Renewable and Sustainable Energy Reviews, 14(9), 2852-2862. http://dx.doi.org/10.1016/j.rser.2010.07.026

Chaiprasert, P., \& Vitidsant, T. (2009). Promotion of coconut shell gasification by steam reforming on nickel-dolomite. American Journal of Applied Sciences, $6(2), \quad 332$. http://dx.doi.org/10.3844/ajassp.2009.332.336

Cui, H., \& Grace, J. R. (2007). Fluidization of biomass particles: A review of experimental multiphase flow aspects. Chemical Engineering Science, 62(1), 45-55. http://dx.doi.org/10.1016/j.ces.2006.08.006

Devi, L., Ptasinski, K. J., \& Janssen, F. J. (2003). A review of the primary measures for tar elimination in biomass gasification processes. Biomass and Bioenergy, 24(2), 125-140. http://dx.doi.org/10.1016/S0961-9534(02)00102-2

Gabra, M., Pettersson, E., Backman, R., \& Kjellström, B. (2001). Evaluation of cyclone gasifier performance for gasification of sugar cane residue_Part 1: gasification of bagasse. Biomass and Bioenergy, 21(5), 351-369. http://dx.doi.org/10.1016/S0961-9534(01)00043-5

Gil, J., Corella, J., Aznar, M. P., \& Caballero, M. A. (1999). Biomass gasification in atmospheric and bubbling fluidized bed: effect of the type of gasifying agent on the product distribution. Biomass and Bioenergy, 17(5), 389-403. http://dx.doi.org/10.1016/S0961-9534(99)00055-0

Karamarkovic, R., \& Karamarkovic, V. (2010). Energy and exergy analysis of biomass gasification at different temperatures. Energy, 35(2), 537-549. http://dx.doi.org/10.1016/j.energy.2009.10.022

Li, X. T., Grace, J. R., Lim, C. J., Watkinson, A. P., Chen, H. P., \& Kim, J. R. (2004). Biomass gasification in a circulating fluidized bed. Biomass and Bioenergy, 26(2), 171-193. http://dx.doi.org/10.1016/S0961-9534(03)00084-9

Lv, P. M., Xiong, Z. H., Chang, J., Wu, C. Z., Chen, Y., \& Zhu, J. X. (2004). An experimental study on biomass air-steam gasification in a fluidized bed. Bioresource technology, 95(1), 95-101. http://dx.doi.org/10.1016/j.biortech.2004.02.003

Mandl, C., Obernberger, I., \& Biedermann, F. (2010). Modelling of an updraft fixed-bed gasifier operated with softwood pellets. Fuel, 89(12), 3795-3806. http://dx.doi.org/10.1016/j.fuel.2010.07.014

Natarajan, E., Nordin, A., \& Rao, A. (1998). Overview of combustion and gasification of rice husk in fluidized bed reactors. Biomass and Bioenergy, 14(5-6), 533-546. http://dx.doi.org/10.1016/S0961-9534(97)10060-5

Pinto, F., Franco, C., Andre, R. N., Tavares, C., Dias, M., Gulyurtlu, I., \& Cabrita, I. (2003). Effect of experimental conditions on co-gasification of coal, biomass and plastics wastes with air/steam mixtures in a fluidized bed system. Fuel, 82(15), 1967-1976. http://dx.doi.org/10.1016/S0016-2361(03)00160-1

Ryu, C., Yang, Y. B., Khor, A., Yates, N. E., Sharifi, V. N., \& Swithenbank, J. (2006). Effect of fuel properties on biomass combustion: Part I. Experiments - fuel type, equivalence ratio and particle size. Fuel, 85(7), 1039-1046. http://dx.doi.org/10.1016/j.fuel.2005.09.019

Skoulou, V., Koufodimos, G., Samaras, Z., \& Zabanioutou, A. (2008). Low temperature gasification of olive kernels in a 5-kW fluidized bed reactor for H2-rich producer gas. International Journal of Hydrogen Energy, 33, 6515-6524. http://dx.doi.org/10.1016/j.ijhydene.2008.07.074

Suarez, J. A. (2003). Physical properties of Cuban coffee husk for use as an energy source. Energy sources, 25(10), 953-959. http://dx.doi.org/10.1080/00908310390232406

Turare, C. (1997). Biomass gasification technology and utilization. Retrieved March 28, 2013, from http://cturare.tripod.com/ove.htm

Warnecke, R. (2000). Gasification of biomass: comparison of fixed bed and fluidized bed gasifier. Biomass and Bioenergy, 18(6), 489-497. http://dx.doi.org/10.1016/S0961-9534(00)00009-X 
Zhang, L. B. (2011). Thermodynamic evaluation of biomass gasification with air in autotherm gasifiers. Thermochimica Acta, 519, 65-71. http://dx.doi.org/10.1016/j.tca.2011.03.005

\section{Copyrights}

Copyright for this article is retained by the author(s), with first publication rights granted to the journal.

This is an open-access article distributed under the terms and conditions of the Creative Commons Attribution license (http://creativecommons.org/licenses/by/3.0/). 